\title{
The non-gastric H,K-ATPase as a tool to study the ouabain-binding site in Na,K-ATPase
}

\author{
Jan Joep H. H. M. De Pont • Herman G. P. Swarts • \\ Anna Karawajczyk • Gijs Schaftenaar • \\ Peter H. G. M. Willems • Jan B. Koenderink
}

Received: 4 January 2008 / Accepted: 23 January 2008 / Published online: 7 March 2008

(C) The Author(s) 2008

\begin{abstract}
Based on studies with chimeras between (non-) gastric H,K-ATPase and Na,K-ATPase, a model for the ouabain binding site has recently been presented (Qiu et al. J.Biol.Chem. 280 (2005) 32349). In this model, hydrogen bonds between specific amino acid residues of $\mathrm{Na}, \mathrm{K}$ ATPase and hydroxyl groups of ouabain play a crucial role. In the present study, a series of ouabain analogues were tested on baculovirus-expressed $\mathrm{Na}, \mathrm{K}$-ATPase and an
\end{abstract}

\footnotetext{
J. J. H. H. M. De Pont $(\bowtie) \cdot$ H. G. P. Swarts •

P. H. G. M. Willems

Department of Biochemistry,

Nijmegen Centre for Molecular Life Sciences, Radboud University Nijmegen Medical Centre,

Nijmegen, The Netherlands

e-mail: J.dePont@ncmls.ru.nl

H. G. P. Swarts

e-mail: H.Swarts@ncmls.ru.nl

P. H. G. M. Willems

e-mail: P.Willems@ncmls.ru.nl

J. B. Koenderink

Department of Pharmacology and Toxicology,

Nijmegen Centre for Molecular Life Sciences,

Radboud University Nijmegen Medical Centre,

Nijmegen, The Netherlands

e-mail: J.Koenderink@ncmls.ru.nl
}

A. Karawajczyk $\cdot$ G. Schaftenaar

Centre for Molecular and Biomolecular Informatics,

Radboud University,

Nijmegen, The Netherlands
A. Karawajczyk
e-mail: A.Karwajczik@cmbi.ru.nl
G. Schaftenaar
e-mail: G.Shaftenaar@cmbi.ru.nl

ouabain-sensitive mutant of non-gastric H,K-ATPase (D312E/ S319G/ A778P/ I795L/ F802C). For each analogue, the results obtained by measuring ATPase inhibition and $\left[{ }^{3} \mathrm{H}\right]$ ouabain replacement agreed rather well. In Na,KATPase, strophanthidin had a 7-10 times higher and digoxin a 4-12 times lower affinity than ouabain. The results of the non-gastric H,K-ATPase mutant were rather similar to that of Na,K-ATPase with exception of dihydroouabain that showed a much lower affinity with the nongastric H,K-ATPase mutant. Docking studies showed that all analogues bind to the same pocket in Na,K-ATPase. However, the amino acids to which hydrogen bonds were formed differed and depended on the availability of hydroxyl or keto groups in the ouabain analogues.

Keywords Non-gastric H,K-ATPase · Na,K-ATPase · Ouabain $\cdot$ Strophanthidin $\cdot$ Digoxin

\section{Introduction}

$\mathrm{Na}, \mathrm{K}-\mathrm{ATPase}$, gastric $\mathrm{H}, \mathrm{K}$-ATPase and non-gastric $\mathrm{H}, \mathrm{K}-$ ATPase form within the family of P-type ATPases a special subfamily (IIc) [1]. Like all other P-type ATPases, its members have a catalytic subunit $(\alpha)$ with a molecular mass around $100 \mathrm{kDa}$. However, the members of this special subfamily cannot function unless a $\beta$-subunit, a glycoprotein with a protein molecular mass of about $35 \mathrm{kDa}$, is present. There are four genes that code for the catalytic subunit of $\mathrm{Na}, \mathrm{K}$-ATPase and one for the gastric as well as one for the non-gastric H,K-ATPase. These catalytic subunits cross the membrane ten times and are for $60-65 \%$ identical. The phylogenic distance between the catalytic subunits of $\mathrm{Na}, \mathrm{K}$-ATPase, gastric H,K-ATPase and nongastric $\mathrm{H}, \mathrm{K}-\mathrm{ATPase}$ is about similar. There are three genes 
that code for $\beta$-subunits of $\mathrm{Na}, \mathrm{K}$-ATPase $\left(\beta_{1-3}\right)$ and one for the $\beta$-subunit of gastric H,K-ATPase $\left(\beta_{\mathrm{HK}}\right)$. The nongastric $\mathrm{H}, \mathrm{K}$-ATPase has no own $\beta$-subunit but most likely uses the $\beta_{1}$-subunit of $\mathrm{Na}, \mathrm{K}$-ATPase [2-4]. Both Na,KATPase $\left(\alpha_{1}\right)$ and the gastric H,K-ATPase work optimally with their own subunits ( $\beta_{1}$ and $\beta_{\mathrm{HK}}$, respectively), but still show some activity with each other's $\beta$-subunit [5]. All ATPases of this family are localised at the plasma membrane. The gastric H,K-ATPase can be found at the apical plasma membrane of gastric parietal cells, the nongastric $\mathrm{H}, \mathrm{K}-\mathrm{ATPase}$ at apical membranes of kidney, colon and prostate glands [6]. Na,K-ATPase is present at the plasma membrane of all mammalian cells. In epithelial cells, it is mainly present on basolateral plasma membranes.

It is a common property of P-type ATPases that during the catalytic cycle, they form a phosphorylated intermediate at an aspartate residue present as part of the sequence DKTP, present in the intracellular-located P-domain. The members of the IIc subfamily have in common that $\mathrm{K}^{+}$stimulates the ATPase reaction through stimulation of the rate of dephosphorylation of this phosphorylated intermediate. The latter cation can be replaced by other monovalent cations like $\mathrm{Rb}^{+}$and $\mathrm{NH}_{4}^{+}$. In the expressed non-gastric $\mathrm{H}, \mathrm{K}-\mathrm{ATPase}$, the affinity for $\mathrm{NH}_{4}^{+}$ is even higher than for $\mathrm{K}^{+}$, and the specific activity with $\mathrm{NH}_{4}^{+}$is much higher than with $\mathrm{K}^{+}[4,7] . \mathrm{K}^{+}$ions and similar cations can be transported into the cell by these ATPases.

Despite these similarities, there are differences between the members of this subfamily. $\mathrm{Na}^{+}$is necessary for the activity of $\mathrm{Na}, \mathrm{K}$-ATPase and does not stimulate gastric H,K-ATPase. Regarding the non-gastric H,K-ATPase there is disagreement whether $\mathrm{Na}^{+}$can activate this ATPase $[4,8,9]$. The gastric $\mathrm{H}$, K-ATPase activity and, most likely, the non-gastric $\mathrm{H}, \mathrm{K}$ ATPase activity are stimulated by $\mathrm{H}^{+}$. This is performed by stimulation of the phosphorylation rate of these ATPases. The stimulations by $\mathrm{Na}^{+}$and $\mathrm{H}^{+}$, respectively, are accompanied by transport of these ions out of the cell.

Another difference is the sensitivity for ouabain and other cardiac glycosides. The Na,K-ATPase of most species is very sensitive towards ouabain. The affinity of the $\alpha_{1}$ form of rat and mouse, however, is about 100 times lower than that of most other species. Lingrel and co-workers have shown that this is due to the presence of an Arg on position 111 and an Asp on position 122 of the catalytic subunits of these rodents, while in all other ouabain-sensitive species, a Gln and an Asn, respectively, are present on these positions [10]. The gastric H,K-ATPase is not sensitive towards ouabain whereas the sensitivity of the non-gastric H,K-ATPase is even lower than that of rodent $\mathrm{Na}, \mathrm{K}$-ATPase, despite the fact that in both H,K-ATPases, a Gln and an Asn are present on the positions comparable to positions 111 and 122 .

In 2000, we surprisingly showed a high affinity for ouabain in a chimera that had, as basis, the gastric H,K-ATPase ( $\alpha$ and $\beta$ subunits) and in which the transmembrane segments M3/
M4 and M5/M6 of the $\alpha$-subunit were replaced by those of $\mathrm{Na}, \mathrm{K}-\mathrm{ATP}$ ase [11]. This chimera was expressed in insect cells using the baculovirus expression system. The four transmembrane segments originating from $\mathrm{Na}, \mathrm{K}$-ATPase still contained 48 amino acids that were specific for this enzyme. Later, we could reduce this number to seven and still kept a high affinity for ouabain $[12,13]$. In the latter studies, we used the oocyte expression system and restricted ourselves to the measurement of ouabain binding. The resulting chimera (EVIGFTD) had a high affinity for ouabain binding in the oocyte system. The seven amino acids $\mathrm{Glu}^{312}, \mathrm{Val}^{314}, \mathrm{Ile}^{315}, \mathrm{Gly}^{319}$ (all from M4), $\mathrm{Phe}^{783}$ (M5), $\mathrm{Thr}^{797}$ and $\mathrm{Asp}^{804}$ (both from M6) were needed for highaffinity ouabain binding in the sense that replacing one of these amino acids by their counterpart from gastric $\mathrm{H}, \mathrm{K}$ ATPase lowered the ouabain binding level considerably. Despite several trials, however, we were not able to get this chimera well expressed in the baculovirus expression system. The latter preparation had a very low ATPase activity and could not be used for obtaining reliable figures for ouabain affinity (unpublished results).

In a next study, we succeeded to convert the rat nongastric H,K-ATPase that has a very low affinity for ouabain, by mutation of only five amino acids into an enzyme with a high affinity for ouabain [14]. Two of these amino acids $\left(\mathrm{Glu}^{312}\right.$ and $\left.\mathrm{Gly}^{319}\right)$ were also found to be important in the study with the gastric H,K-ATPase chimera EVIGFTD, whereas three others Pro ${ }^{778}, \mathrm{Leu}^{795}$ and $\mathrm{Cys}^{802}$ were new. This chimera (EGPLC) could, in contrast to chimera EVIGFTD, well be expressed in the baculovirus system and showed a high $\mathrm{NH}_{4}^{+}$-activated ATPase activity that could be inhibited by low ouabain concentrations [14].

In the course of the study with the EVIGFTD chimera, a docking study with ouabain in Na,K-ATPase homologue based on the 1WPG structure (close to the $\mathrm{E}_{2} \mathrm{P}$ form of $\mathrm{Ca}^{2+}$-ATPase) was performed. The resulting model showed important roles for several of the amino acids that were identified in both studies with the chimeras $[13,14]$. In addition, the two amino acids discovered by Lingrel's group [15] were very important in the model. They formed hydrogen bonds with hydroxyl groups coupled to the steroid skeleton of ouabain. $\mathrm{Gl}^{111}$ had hydrogen bonds with both $\mathrm{OH}$ groups on places 1 and 11 of the steroid skeleton of ouabain, whereas $\mathrm{Asn}^{122}$ had a hydrogen bridge with the $\mathrm{OH}$ on position 11 (see Fig. 1). Such a model explains, at least qualitatively, the lower affinity for ouabain of rat and mouse Na,K-ATPase.

There are many heart glycosides that can inhibit $\mathrm{Na}, \mathrm{K}$ ATPase. They differ from ouabain by the absence or type of sugars, by the functional groups attached to the steroid skeleton and by the presence of a double bond in the lactone ring. One would expect that this would lead to large differences in binding affinities between these analogues. Moreover, the species difference as observed with ouabain 
Fig. 1 Chemical structure of the ouabain analogues

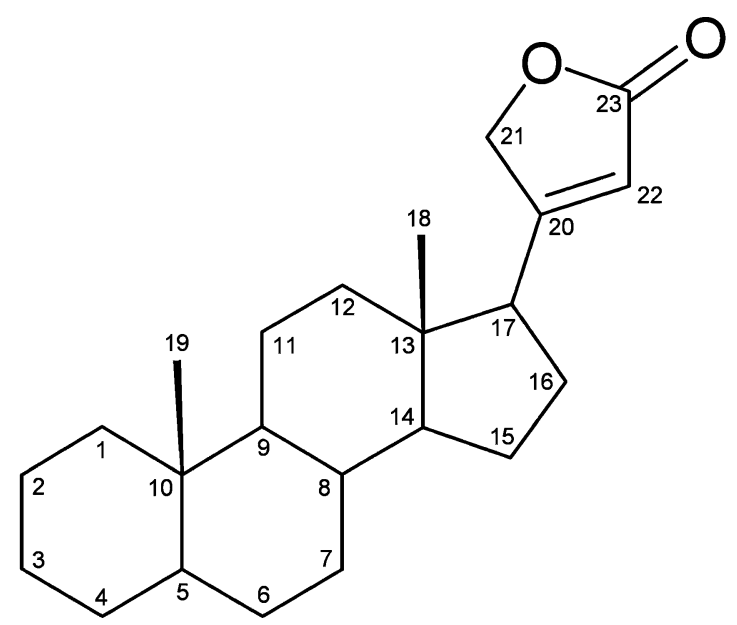

\begin{tabular}{|lllllllll|}
\hline \multicolumn{1}{|c}{ residue number } & 3 & 1 & 19 & 11 & 12 & 14 & 5 & others \\
\hline Ouabain & -rhamnose & $-\mathrm{OH}$ & $-\mathrm{OH}$ & $-\mathrm{OH}$ & & $-\mathrm{OH}$ & $-\mathrm{OH}$ & \\
Ouabagenin & $-\mathrm{H}$ & $-\mathrm{OH}$ & $-\mathrm{OH}$ & $-\mathrm{OH}$ & & $-\mathrm{OH}$ & $-\mathrm{OH}$ & \\
Strophanthidin & $-\mathrm{H}$ & $-\mathrm{H}$ & $=\mathrm{O}$ & $-\mathrm{H}$ & & $-\mathrm{OH}$ & $-\mathrm{OH}$ & \\
Dihydro-ouabain & - rhamnose & $-\mathrm{OH}$ & $-\mathrm{OH}$ & $-\mathrm{OH}$ & & $-\mathrm{OH}$ & $-\mathrm{OH}$ & C20-C22 saturated \\
Digoxin & - trisdigitoxose & & & & $-\mathrm{OH}$ & $-\mathrm{OH}$ & $-\mathrm{H}$ & \\
Digoxigenin & $-\mathrm{H}$ & & & & $-\mathrm{OH}$ & $-\mathrm{OH}$ & $-\mathrm{H}$ & \\
\hline
\end{tabular}

would be absent for analogues in which these particular hydrogen bridges could not be formed. By testing these analogues on the EGPLC mutant, one could moreover establish whether or not the binding site for heart glycosides in this mutant is completely similar to that in $\mathrm{Na}$, K-ATPase. We studied, in addition to ouabain, the following five analogues: digoxin, dihydro-ouabain, digoxigenin, strophanthidin and ouabagenin. We used the baculovirus-expressed rat Na,K-ATPase, the QN mutant of rat Na,K-ATPase (Arg and Asp on positions 111 and 121 replaced by Gln and Asn, respectively), the rat non-gastric H,K-ATPase and its EGPLC mutant. We determined the affinity of these compounds in two different ways. We measured their inhibitory potency in ATPase assays (for Na,K-ATPase and its QN mutant with both $\mathrm{Na}^{+}$and $\mathrm{K}^{+}$as activating ions and for non-gastric $\mathrm{H}$, $\mathrm{K}$-ATPase and the EGPLC mutant with $\mathrm{NH}_{4}^{+}$as activating ion). In addition, we determined the apparent affinity for these compounds when they competed with $\left[{ }^{3} \mathrm{H}\right]$-ouabain for the binding to these constructs.

\section{Materials and methods}

Construction of recombinant $\mathrm{Na}, \mathrm{K}-\mathrm{ATP}$ ase and non-gastric H,K-ATPase

The chimeras and mutants used in this study were: the rat Na,K-ATPase $\alpha_{1}$-subunit (wild type), the R111Q/ D122N mutant $(\mathrm{QN})$ of this enzyme [10, 11], the rat non-gastric $\mathrm{H}$, K-ATPase $\alpha_{2}$-subunit [13] as well as its EGPLC mutant
(D312E, S319G, A778P, I795L, F802C) [14]. Generation of the vectors containing the $\alpha_{2}$-subunit of rat non-gastric H,K-ATPase with the $\beta_{1}$-subunit of rat Na,K-ATPase or the $\alpha_{1}$-subunit of rat Na,K-ATPase with the $\beta_{1}$-subunit of sheep Na,K-ATPase that were suited for the baculovirus expression system, has been reported before [5, 14].

Preparation of Sf9 membranes

Sf9 cells were grown at $27^{\circ} \mathrm{C}$ in $100-\mathrm{ml}$ spinner flask cultures as described by Klaassen et al. [16]. For expression

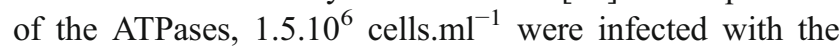
proper virus at a multiplicity of infection of $1-3$ in the presence of $1 \%(v / v)$ ethanol and $0.1 \%(w / v)$ pluronic F-68 (ICN, Aurora, OH, USA) in Xpress medium (Biowittaker, Walkersville, MD, USA) as described before [17]. After 3 days, Sf 9 cells were harvested by centrifugation at $2,000 \times \mathrm{g}$ for $5 \mathrm{~min}$. The cells were washed once at $0^{\circ} \mathrm{C}$ with $0.25 \mathrm{M}$ sucrose, $2 \mathrm{mM}$ EDTA and $25 \mathrm{mM}$ Hepes/Tris ( $\mathrm{pH}$ 7.0), resuspended in sucrose/EDTA/Tris buffer and sonicated at $60 \mathrm{~W}$ (Branson Power Company, Denbury, CT, USA) for $30 \mathrm{~s}$ at $0^{\circ} \mathrm{C}$. After centrifugation for $30 \mathrm{~min}$ at $10,000 \times \mathrm{g}$ the supernatant was collected and recentrifuged for $60 \mathrm{~min}$ at $100,000 \times g$ at $4^{\circ} \mathrm{C}$. The pelleted membranes were resuspended in the above-mentioned buffer and stored at $-20^{\circ} \mathrm{C}$.

Biochemical methods

Protein determination The protein concentrations were quantified with the modified Lowry method according to Peterson [18] using bovine serum albumin as a standard. 
$\left[{ }^{3}\right.$ H]Ouabain binding Sf9 membranes $( \pm 100 \mu \mathrm{g})$ were incubated at room temperature in $50 \mathrm{mM}$ Tris-acetic acid (pH 7.0), $1 \mathrm{mM}$ ATP, $5.0 \mathrm{mM} \mathrm{MgCl} 2,25 \mathrm{nM}\left[{ }^{3} \mathrm{H}\right]$ ouabain, $1 \mathrm{mM} \mathrm{H}_{3} \mathrm{PO}_{4}$ at a final volume of $50 \mu \mathrm{l}$ in the presence of the concentrations of ouabain or its analogues as indicated. After $2 \mathrm{~h}$, the reaction mixture was chilled for $15 \mathrm{~min}$ on ice. The ouabain-protein complex was collected by filtration over a 0.8- $\mu \mathrm{m}$ membrane filter (Schleicher and Schuell, Dassel, Germany). After washing twice with ice-cold water, radioactivity was analysed by liquid scintillation analysis.

ATPase assay The ATPase activity was determined using a radiochemical method [19]. For this purpose, $10-30 \mu \mathrm{g}$ of Sf 9 membranes were added to $100 \mu l$ of medium containing $2 \mathrm{mM} \mathrm{Mg}-\left[\gamma_{-}{ }^{32} \mathrm{P}\right]-\mathrm{ATP}, 10 \mathrm{mM} \mathrm{NH}_{4} \mathrm{Cl}$ (nongastric H,K-ATPase or its EGPLC mutant), $100 \mathrm{mM} \mathrm{NaCl}$ and $10 \mathrm{mM} \mathrm{KCl}(\mathrm{Na}, \mathrm{K}-\mathrm{ATPase}$ wild type and its QN mutant), $0.8 \mathrm{mM} \mathrm{MgCl}_{2}, 0.1 \mathrm{mM}$ EGTA, $0.2 \mathrm{mM}$ EDTA, $1 \mathrm{mM}$ TrisN $_{3}, 50 \mathrm{mM}$ Tris- $\mathrm{HCl}$ (pH 7.0) and concentrations of ouabain or its analogues as indicated. After incubation for $60 \mathrm{~min}$ at $37^{\circ} \mathrm{C}$, the reaction was stopped by adding $500 \mu 110 \%(w / v)$ charcoal in $6 \%(v / v)$ trichloroacetic acid and after $10 \mathrm{~min}$ at $0^{\circ} \mathrm{C}$, the mixture was centrifuged for $10 \mathrm{~s}$ at $10,000 \times g$. To $0.15 \mathrm{ml}$ of the clear supernatant, containing the liberated inorganic phosphate $\left({ }^{32} \mathrm{P}_{\mathrm{i}}\right), 3 \mathrm{ml}$ OptiFluor (Canberra Packard, Tilburg, The Netherlands) was added and the mixture was analysed by liquid scintillation analysis. In general, blanks were prepared by incubating in the absence of membranes. ATPase activity is presented as the difference in activity between membranes of ATPase-expressing cells and mock-infected cells.

\section{Docking of ouabain}

The homology model of the QN mutant of rat Na,K-ATPase [13], based on an $\mathrm{E}_{2}$-P-like structure of $\mathrm{Ca}^{2+}$-ATPase (1WPG; [20]), was used for in silico docking with the FlexX program [21], version 1.13.5 L. FlexX predicts the conformations of a set of energetically favourable molecular complexes consisting of the ligand bound to the active site of the protein. The complexes were labelled with a score that approximates binding energy. Because of the huge size of the ATPase model, placement of the ligand was restricted to the previously postulated binding pocket on the extracellular side of the membrane [12]. Besides an overall pocket, a sub-pocket was defined to include residues known from mutation experiments to be important for ligand binding. The use of a sub-pocket lets FlexX place the base fragment (the first placed fragment of the ligand) near one of the residues in the sub-pocket. The rest of the ligand still has the freedom to completely move away from these residues as long as the ligand remains within the overall pocket.
The starting structure for ouabain and its analogues was obtained from the Cambridge Structural Database [22]. Hydrogens were added interactively with Molden package [23]. Molden was also used to assign the atom types of the Sybyl force field. This assignment was checked by visual inspection. Bond lengths and bond angles were optimised with the Sybyl force field.

FlexX produced a number of protein-ligand complexes, of which the ten best scoring ones were inspected visually. These so-called poses showed little variation in geometries. The best scoring pose was used for this work. As FlexX keeps the protein completely fixed, the amino acid sidechain rotamers could not be expected to be optimal, as the homology model was built in absence of ouabain. Consequently, the best scoring pose was subjected to an additional energy minimization with the Yamber force field $[24,25]$, which resulted in improved hydrogen bonding patterns.

\section{Calculations}

$\mathrm{IC}_{50}$ values were determined by analysing the plots using the non-linear curve-fitting program (Hill equation function) of Orgin 6.1 (OriginLab Corp., Northampton, MA, USA). Data are presented as mean values with standard error of the mean of the number experiments. Differences were tested for significance by means of Student's $t$ test.

\section{Materials}

Ouabain (O3125), ouabagenin (O2627), digoxigenin (D9026), dihydro-ouabain (D0670), digoxin (D6003) and strophanthidin (S6626) were from Sigma-Aldrich, St. Louis, MO, USA $\left[{ }^{3} \mathrm{H}\right]$ Ouabain $\left(17 \mathrm{Ci} \mathrm{mmol}{ }^{-1}\right)$ and $\left[\gamma-{ }^{32} \mathrm{P}\right]$ ATP $\left(3000 \mathrm{Ci} \mathrm{mmol}^{-1}\right)$ were purchased from Amersham Pharmacia (Buckinghamshire, United Kingdom).

\section{Results}

\section{ATPase inhibition studies}

The five ouabain analogues (structures given in Fig. 1) were chosen to get a series of analogues with limited differences as compared to ouabain. Whereas ouabain has a rhamnose sugar coupled to the $\mathrm{OH}$ group on position 3 of the steroid skeleton, ouabagenin lacks this sugar. In dihydro-ouabain, the lactone ring is saturated. Strophanthidin lacks, like ouabagenin, not only the rhamnose sugar but also the two hydroxyl groups that in ouabain are coupled to the steroid on positions 1 and 11. In addition, a keto group replaces the hydroxyl group on position 19. In digoxin, the rhamnose from ouabain is replaced by trisdigitoxose. 
Digoxin also lacks the $\mathrm{OH}$ groups on positions $1,5,11$ and 19 of the steroid skeleton and has an additional $\mathrm{OH}$ group on position 12. Digoxigenin is similar to digoxin but lacks the sugar chain.

Figure 2 shows that all ouabain analogues only inhibit the $\mathrm{Na}, \mathrm{K}$-ATPase activity of the rat wild-type enzyme when very high concentrations were applied. Much lower concentrations were needed when the QN analogue of $\mathrm{Na}, \mathrm{K}-$ ATPase was used. This means that the presence of an Arg on position 111 and an Asp on position 122 in the rat wildtype enzyme not only lowers the affinity for ouabain but also for the five studied analogues. Table 1 gives the $\mathrm{IC}_{50}$ values, both absolutely (line $\mathrm{A}$ ) and relative to the value with ouabain (line B). The Table shows that the $\mathrm{IC}_{50}$ value for strophanthidin is lower than for ouabain. The $\mathrm{IC}_{50}$ values for digoxin and ouabagenin are higher than that of ouabain, whereas those of dihydro-ouabain and digoxigenin do not significantly differ with that of ouabain.

Figure 3 shows that the wild-type non-gastric $\mathrm{H}, \mathrm{K}$ ATPase activity was very insensitive to ouabain and its analogues. Due to the limited solubility of some of these analogues, it is impossible to measure $\mathrm{IC}_{50}$ values for this inhibition. The $\mathrm{NH}_{4}^{+}$-stimulated ATPase activity of the EGPLC mutant, on the other hand, could be inhibited by low concentrations of all analogues. Compared to ouabain, both strophanthidin and digoxin had slightly lower $\mathrm{IC}_{50}$ values, whereas these values for digoxigenin and ouabagenin were two and eight times higher, respectively. The $\mathrm{IC}_{50}$ value for dihydro-ouabain was more than 40 times higher than that for ouabain.
Fig. 2 Inhibition of the $\mathrm{Na}^{+}$and $\mathrm{K}^{+}$-activated ATPase activity of Na,K-ATPase (closed symbols) and its QN-mutant (open symbols) by ouabain and five of its analogues
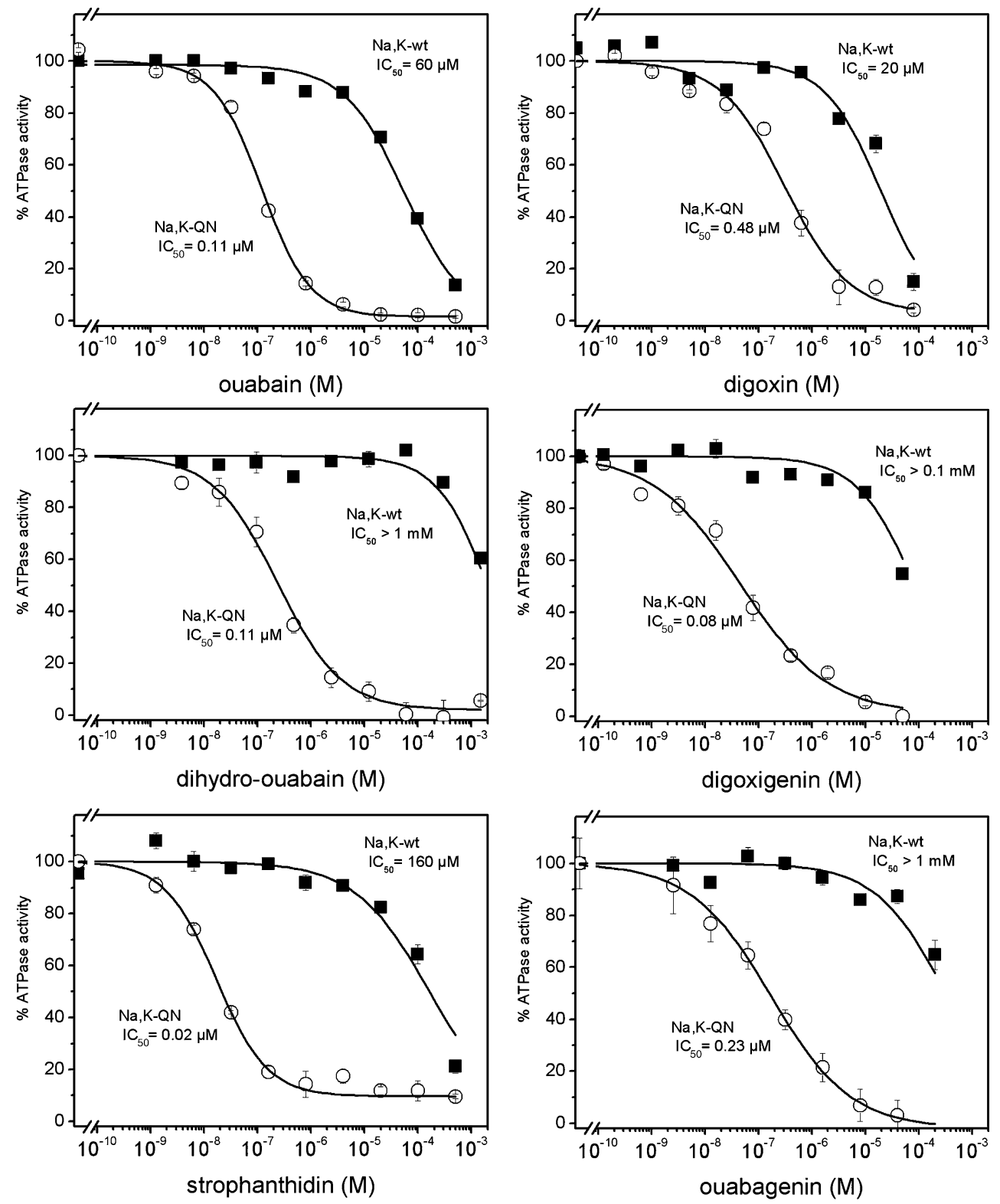
Table 1 The effect of the ouabain analogs in ATPase activity measurements and $\left[{ }^{3} \mathrm{H}\right]$-ouabain displacement studies

\begin{tabular}{|c|c|c|c|c|c|c|c|c|}
\hline & & $\mathrm{n}$ & ouabain & digoxin & dihydro-ouabain & digoxigenin & strophanthidin & ouabagenin \\
\hline \multicolumn{9}{|c|}{ ATPase activity measurements } \\
\hline \multirow[t]{4}{*}{ A. $\mathrm{IC}_{50}$ values $(\mu \mathrm{M})$} & $\mathrm{Na}, \mathrm{K}$-ATPase (wt) & 2 & $60 \pm 2$ & $20 \pm 2$ & $>1000$ & $>100$ & $160 \pm 20$ & $>1000$ \\
\hline & $\mathrm{Na}, \mathrm{K}$-ATPase (QN) & $3-4$ & $0.11 \pm 0.024$ & $0.48 \pm 0.227$ & $0.11 \pm 0.010$ & $0.08 \pm 0.031$ & $0.02 \pm 0.002 *$ & $0.23 \pm 0.023$ \\
\hline & $\mathrm{HK} \alpha 2$-ATPase (wt) & 3 & $>200$ & $>100$ & $>1000$ & $>100$ & $>1000$ & $>500$ \\
\hline & EGPLC mutant & 4 & $0.10 \pm 0.005$ & $0.07 \pm 0.010^{*}$ & $4.7 \pm 0.75^{*}$ & $0.20 \pm 0.048$ & $0.05 \pm 0.005^{*}$ & $0.80 \pm 0.246$ \\
\hline \multirow[t]{2}{*}{ B. Relative to ouabain } & $\mathrm{Na}, \mathrm{K}$-ATPase (QN) & & $1.00 \pm 0.300$ & $4.2 \pm 2.20^{*}$ & $1.01 \pm 0.232$ & $0.66 \pm 0.308$ & $0.14 \pm 0.035^{*}$ & $2.0 \pm 0.47^{*}$ \\
\hline & EGPLC mutant & & $1.00 \pm 0.070$ & $0.65 \pm 0.104$ & $46 \pm 7.8^{*}$ & $2.0 \pm 0.49$ & $0.48 \pm 0.055^{*}$ & $7.9 \pm 2.47^{*}$ \\
\hline \multicolumn{3}{|c|}{ C. Relative to Na,K-ATPase (QN) } & $1.00 \pm 0.308$ & $0.15 \pm 0.083$ & $45.8 \pm 13.05$ & $3.0 \pm 1.6$ & $3.4 \pm 0.91$ & $3.9 \pm 1.53$ \\
\hline \multicolumn{9}{|c|}{ Ouabain replacement studies } \\
\hline \multirow[t]{2}{*}{ D. $\mathrm{IC}_{50}$ values $(\mu \mathrm{M})$} & $\mathrm{Na}, \mathrm{K}$-ATPase (QN) & 4 & $0.07 \pm 0.006$ & $0.78 \pm 0.252 *$ & $0.08 \pm 0.002 *$ & $0.02 \pm 0.005^{*}$ & $0.01 \pm 0.002 *$ & $0.05 \pm 0.019$ \\
\hline & EGPLC mutant & 4 & $0.31 \pm 0.040$ & $0.76 \pm 0.214$ & $27 \pm 3.2 *$ & $0.75 \pm 0.268$ & $0.17 \pm 0.032 *$ & $2.8 \pm 1.31$ \\
\hline \multirow[t]{2}{*}{ E. Relative to ouabain } & NaK-ATPase (QN) & & $1.00 \pm 0.127$ & $11.6 \pm 3.90^{*}$ & $1.21 \pm 0.112$ & $0.25 \pm 0.078 *$ & $0.10 \pm 0.031 *$ & $0.70 \pm 0.290$ \\
\hline & EGPLC mutant & & $1.00 \pm 0.181$ & $2.4 \pm 0.75^{*}$ & $86 \pm 15.0^{*}$ & $2.4 \pm 0.91^{*}$ & $0.54 \pm 0.124$ & $8.9 \pm 4.33 *$ \\
\hline \multicolumn{3}{|c|}{ F. Relative to Na,K-ATPase (QN) } & $1.00 \pm 0.221$ & $0.21 \pm 0.095$ & $71 \pm 14.1$ & $9.5 \pm 4.62$ & $5.2 \pm 1.95$ & $12.8 \pm 8.12$ \\
\hline
\end{tabular}

Data from Figs. 2, 3 and 4

$A$ and $D$ inhibition data ( $\mathrm{IC}_{50}$ values) in $\mu \mathrm{M}, B$ and $E \mathrm{IC}_{50}$ values relative to ouabain, $C$ and $F$ data from B and $\mathrm{E}$ relative to Na,K-ATPase (QN; relative ratio $\mathrm{EGPLC} / \mathrm{Na}, \mathrm{K}-\mathrm{ATPase}(\mathrm{QN})$

$* P<0.05$

Comparison of the $\mathrm{IC}_{50}$ values for ouabain and its analogues on the ATPase activity of Na,K-ATPase (QN) and the EGPLC mutant of non-gastric ATPase (line C) shows that ouabain inhibited both enzymes equally potently. Remarkably, the ATPase activity of the EGPLC mutant was even relatively better inhibited by digoxin than by ouabain, whereas it was much less inhibited by dihydroouabain. Strophanthidin, ouabagenin and digoxigenin inhibited the activity of the EGPLC mutant about three times less than that of Na,K-ATPase (QN).

\section{$\left[{ }^{3} \mathrm{H}\right]$ ouabain replacement studies}

Because of the very low affinity for ouabain of the unmodified rat $\mathrm{Na}, \mathrm{K}$-ATPase and the rat non-gastric $\mathrm{H}, \mathrm{K}$ ATPase, $\left[{ }^{3} \mathrm{H}\right]$ ouabain replacement studies could only be carried out with the QN-analogue of Na,K-ATPase and the EGPLC mutant of non-gastric H,K-ATPase. Figure 4 shows that all analogues are able to displace $\left[{ }^{3} \mathrm{H}\right]$ ouabain, either when bound to the Na,K-ATPase (QN) or to the EGPLC mutant of non-gastric $\mathrm{H}, \mathrm{K}$-ATPase. The $\mathrm{IC}_{50}$ values for these replacements are presented in Table 1, both as absolute values (line $\mathrm{D}$ ) and relative to the $\mathrm{IC}_{50}$ value for ouabain (line E). When the QN mutant of Na,K-ATPase was used strophanthidin, digoxigenin and ouabagenin had a two- to tenfold lower $\mathrm{IC}_{50}$ value than ouabain. Digoxin, however, had an 11 times higher $\mathrm{IC}_{50}$ value. $\mathrm{The}^{\mathrm{IC}_{50}}$ value for dihydro-ouabain was slightly higher than that of ouabain.

When $\left[{ }^{3} \mathrm{H}\right]$ ouabain replacement studies were carried out with the EGPLC mutant of non-gastric H,K-ATPase, strophanthidin had a two times lower $\mathrm{IC}_{50}$ value than ouabain. $\mathrm{The} \mathrm{IC}_{50}$ values for both digoxin and digoxigenin were about twice as high and that of ouabagenin was about nine times as high as that of ouabain. The $\mathrm{IC}_{50}$ value for dihydro-ouabain was more than 80 times as high as that of ouabain.

As is clear from both Fig. 4 and line F from Table 1, the EGPLC mutant binds digoxin relatively better than the QN mutant of $\mathrm{Na}, \mathrm{K}$-ATPase. The EGPLC mutant binds digoxigenin, strophanthidin and ouabagenin with a five to ten times relative lower affinity than Na,K-ATPase. The EGPLC mutant has a very low affinity for dihydro-ouabain.

\section{Comparison of both methods}

The results presented in lines $\mathrm{B}$ and $\mathrm{E}$ of Table 1 are graphically presented in Fig. 5. Both for the QN mutant of $\mathrm{Na}, \mathrm{K}-\mathrm{ATPa} e$ (Fig. 5a) and the EGPLC mutant of non gastric H,K-ATPase (Fig. 5b), there is a very good correlation between the results of the ATPase inhibition and the $\left[{ }^{3} \mathrm{H}\right]$ ouabain replacement experiments. This indicates that the $\mathrm{IC}_{50}$ values for a single compound and ATPase preparation, obtained by measuring the effects on ATPase inhibition and ouabain replacement, are within a narrow range.

\section{Docking experiments}

Similarly, as described earlier for ouabain [13], docking experiments were carried out with the five analogues in a homology model of the $\mathrm{E}_{2}-\mathrm{P}$ form of human $\mathrm{Na}, \mathrm{K}-\mathrm{ATPase}$, based on the 1WPG structure of $\mathrm{Ca}^{2+}$-ATPase. The human ATPase is comparable to the QN mutant. Although all 
Fig. 3 Inhibition of the $\mathrm{NH}_{4}^{+}$activated ATPase activity of non-gastric H,K-ATPase (open symbols) and its EGPLC mutant (closed symbols) by ouabain and five of its analogues
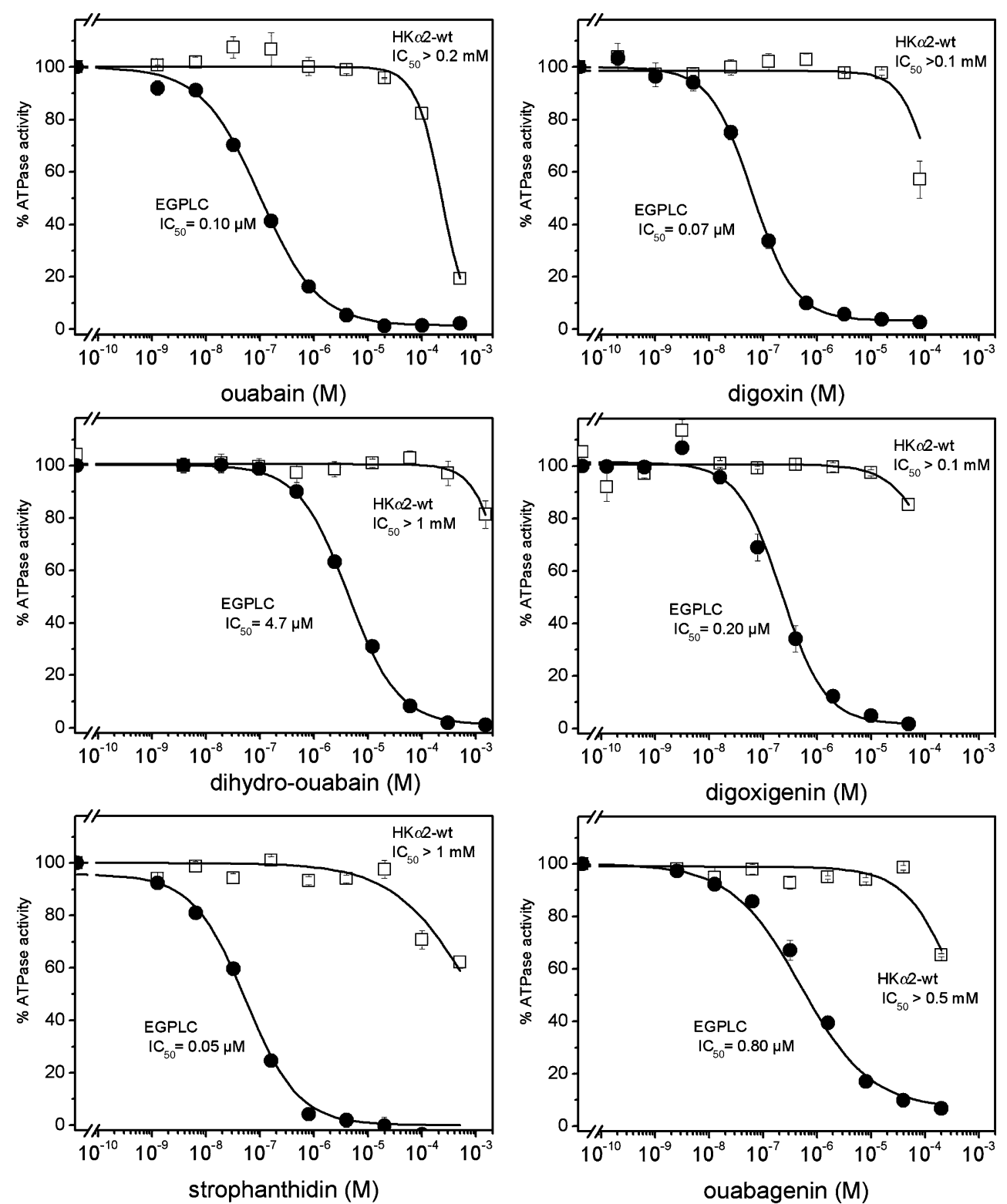

analogues bound in the same pocket as ouabain, they interacted in part with different amino acid residues. As an example, the binding of strophanthidin is presented in Fig. 6. Table 2 gives a summary of the hydrogen bridges with $\mathrm{Na}, \mathrm{K}$-ATPase that were found for the various ouabain analogues. All analogues, except digoxin, form one or more hydrogen bridges from hydroxyl groups bound to the steroid skeleton with $\mathrm{Gln}^{111}$. The latter residue forms normally a hydrogen bridge with $\mathrm{Asn}^{122}$. This hydrogen bridge is broken when these analogues are present. Only with digoxin does a binding with $\operatorname{Gln}^{111}$ not occur and the hydrogen bridge with $\mathrm{Asn}^{122}$ stays intact. Most analogues also form hydrogen bridges with $\mathrm{Arg}^{972}$. This residue forms normally a salt bridge with $\mathrm{Glu}^{908}$. With ouabain and dihydro-ouabain, this salt bridge is still intact but with digoxin, digoxigenin, strophanthidin and ouabagenin, the binding energy of the complex between drug and $\mathrm{Na}, \mathrm{K}$ ATPase is apparently sufficient to open this salt bridge. Table 2 also shows that in case sugars are present, they always couple to $\mathrm{Glu}^{312}$ with one or more hydrogen bridges. In most cases, the lactone ring binds to the three adjacent amino acid residues $\mathrm{Thr}^{797}$, $\mathrm{Val}^{798}$ and $\mathrm{Thr}^{799}$, in part, through an interaction with the backbone amide groups. There is no clear hydrogen bonding of the lactone ring in dihydro-ouabain because of a different orientation of this ring.

Docking experiments were also carried out with the rat wild-type Na,K-ATPase; $\operatorname{Arg}^{111}$ of the wild type is more bulky than $\mathrm{Gln}^{111}$ of the QN mutant. Only two of the possible rotamers of $\mathrm{Arg}^{111}$ do not substantially decrease the space available for the ligands. Both rotamers form a salt bridge with $\mathrm{Asp}^{122}$ but, in addition, offer interaction 
Fig. $4\left[{ }^{3} \mathrm{H}\right]$ ouabain displacement experiments of $\mathrm{Na}, \mathrm{K}-$ ATPase (QN; open symbols) and the non-gastric H,K-ATPase EGPLC mutant (closed symbols) in the presence of $\mathrm{Pi}$
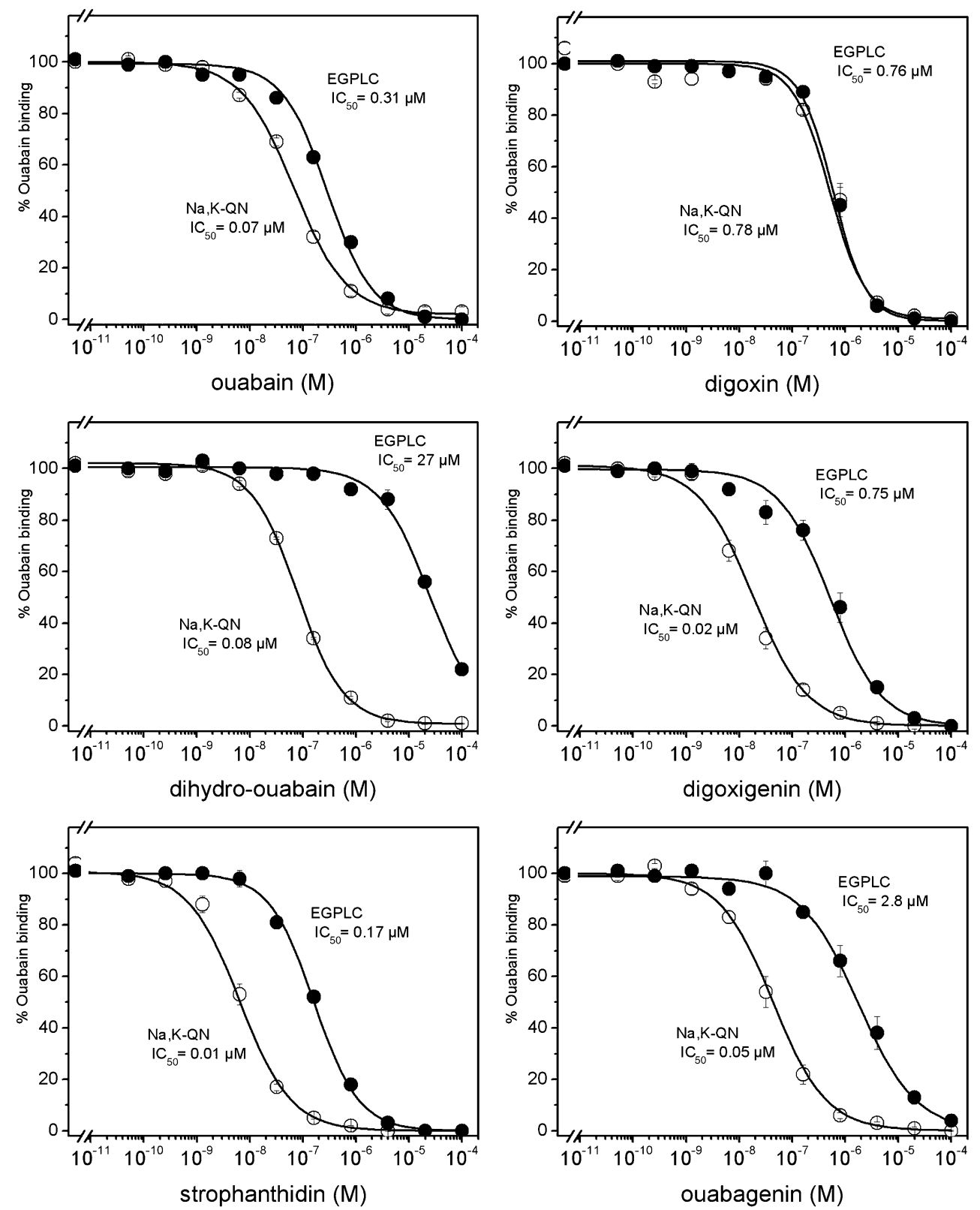

Fig. 5 Correlation between the $\mathrm{IC}_{50}$ values obtained by measuring the inhibition of the ATPase activity and the displacement of $\left[{ }^{3} \mathrm{H}\right]$ ouabain binding by the ouabain analogues in $\mathrm{Na}, \mathrm{K}$-ATPase (QN) and $\mathrm{H}, \mathrm{K}$ ATPase EGPLC. The reciprocal value of the $\mathrm{IC}_{50}$ value obtained with ouabain was set at 1 and all other values were related to this value

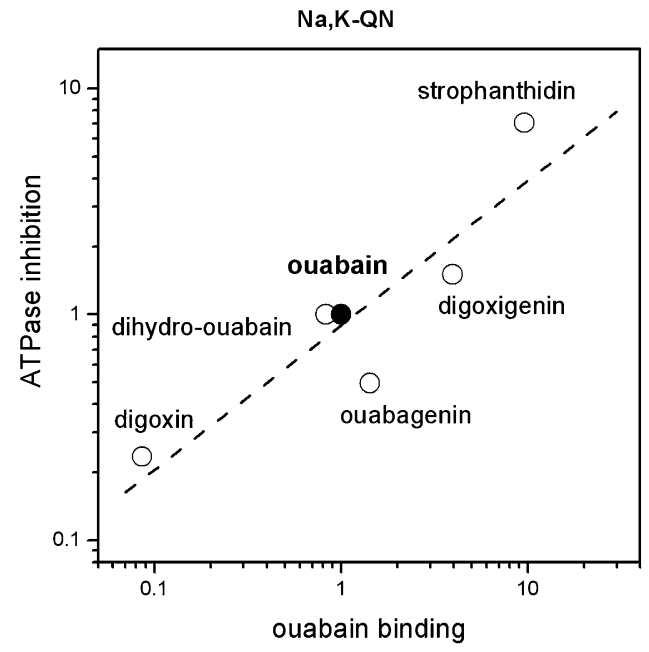

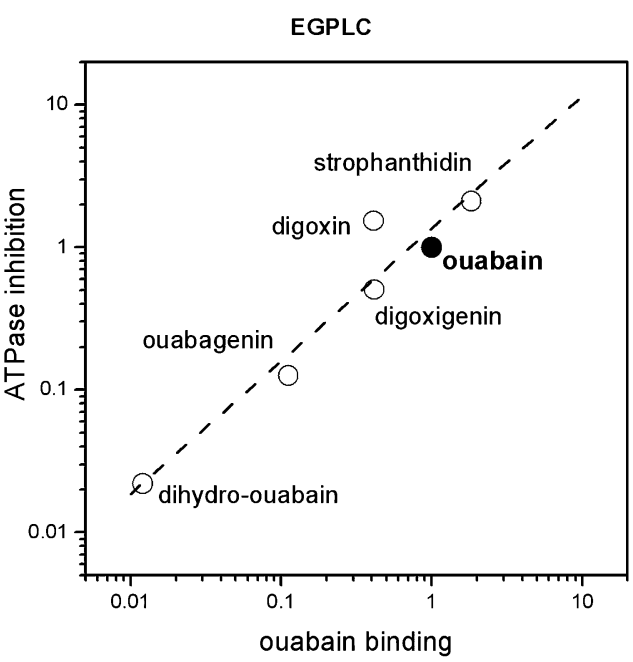




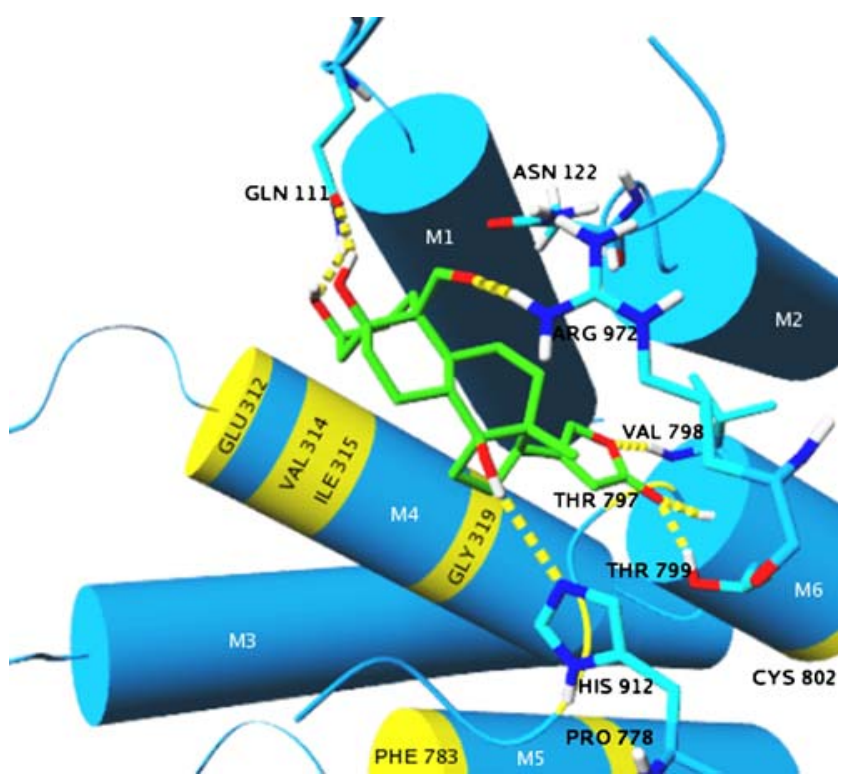

Fig. 6 Molecular model of docking of strophanthidin in $\mathrm{Na}, \mathrm{K}-$ ATPase. Nitrogen is colored blue, oxygen red and carbon cyan or green (in strophanthidin). Hydrogen bonds are shown as yellow dotted lines. Surrounding parts of the structure have been hidden for clarity. Amino acids that were shown to be essential for ouabain binding [13, 14] are indicated in yellow. Images were created with Yasara (www. yasara.org)

sites for the ligands. Of these two rotamers, only one yields successful docking results for more than one ligand. With exception of strophanthidin, these docking poses are different from that with the QN mutant.

\section{Discussion}

Two methods were used in this study to determine the apparent affinities for some ouabain analogues. On the one hand, the ability to compete with $\left[{ }^{3} \mathrm{H}\right]$ ouabain for the binding to several ATPases and on the other hand, the inhibitory effect on the activities of these ATPases. Because of the very low binding level of $\left[{ }^{3} \mathrm{H}\right]$ ouabain to wild-type rat $\mathrm{Na}, \mathrm{K}-\mathrm{ATPa}$ a and rat non-gastric $\mathrm{H}, \mathrm{K}$-ATPase, the ouabain replacement method could not be used with these preparations. Only with the QN mutant of rat Na,K-ATPase and the EGPLC mutant of non-gastric H,K-ATPase was the use of both methods possible. Although the results between the QN mutant and the EGPLC mutant for the various analogues differ, the $\mathrm{IC}_{50}$ values obtained with both methods (ATPase inhibition measurements and $\left[{ }^{3} \mathrm{H}\right]$ ouabain replacement studies) are, in general, rather similar for a single drug used with one of both ATPases. Our findings for Na,K-ATPase (QN) contrast with those of Paula et al. [26] who carried out apparently similar studies on lamb kidney ATPase (that also contains a Gln on position 111 and an Asn on position 122) with a very large series of

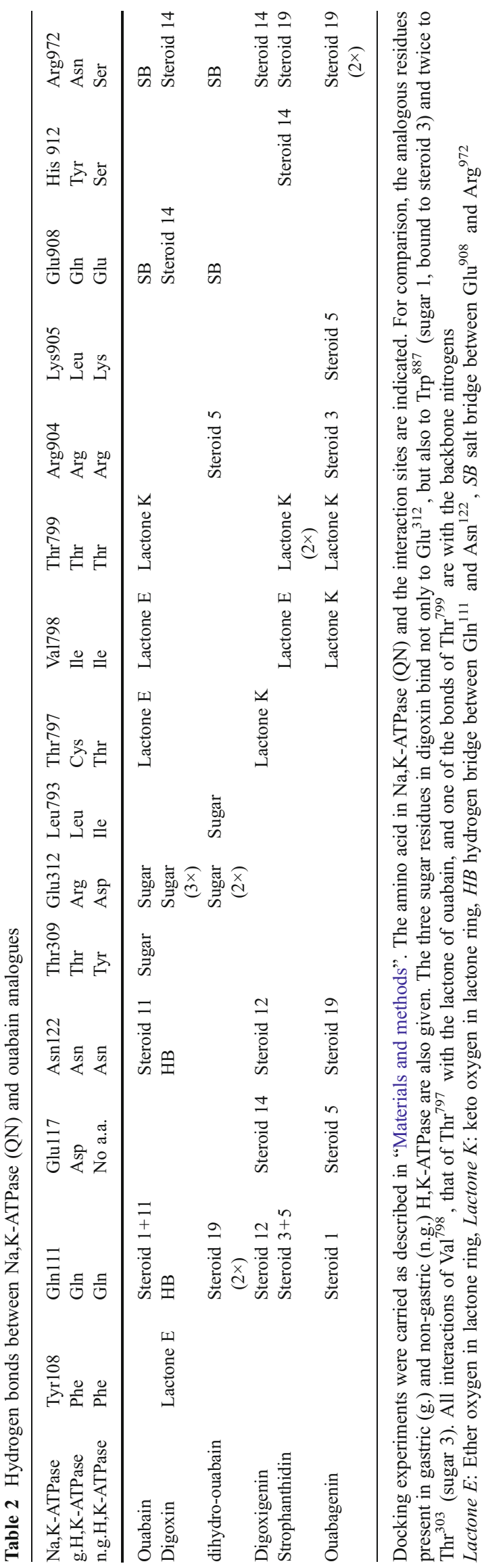


ouabain analogues. Whereas their results on $\mathrm{Na}, \mathrm{K}$-ATPase inhibition, with exception of those for strophanthidin, fit reasonably well with our findings, Paula et al. [26] found for all inhibitors, except digoxin, much higher $\mathrm{IC}_{50}$ values in ouabain replacement studies than we found in the present study (Table 3). An explanation for this discrepancy cannot yet be given. A good correlation between $\left[{ }^{3} \mathrm{H}\right]$ ouabain replacement and ATPase inhibition, as found by us, is what would be expected.

For the wild-type rat Na,K-ATPase, only ATPase inhibition measurements could be carried out. As shown in Fig. 3 and Table 1, the $\mathrm{IC}_{50}$ values were very high and only a lower limit of the $\mathrm{IC}_{50}$ values for dihydro-ouabain, digoxigenin and ouabagenin could be given. However, it is clear that the difference in $\mathrm{IC}_{50}$ value for ouabain between the wild-type enzyme and the QN mutant is valid not only for ouabain but also for all the other tested analogues. In our published model for the ouabain-binding site [13], the hydrogen bridges between $\operatorname{Gln}^{111}$ and $\mathrm{Asn}^{122}$ at the one side and the hydroxyl groups on positions 1 and 11 of the steroid skeleton at the other side play an essential role. Because some or all of these hydroxyl groups are absent or are located on different positions in the analogues, there must be another explanation for the low affinity of all these inhibitors for the rat wild-type Na,K-ATPase. It might be that the charged residues at the positions 111 and 122 in rodent species prohibit the entrance of these compounds to the binding pocket. The docking experiments suggest that, in particular, the (bulky) Arg residue on position 111 occupies part of the binding pocket and so prevents binding of ouabain and its analogues. It might also be that $\operatorname{Arg}^{111}$ and $\mathrm{Asp}^{122}$ form a salt bridge that is difficult to break.

There is general agreement that ouabain binds to $\mathrm{Na}, \mathrm{K}-$ ATPase at the extracellular surface of the $\alpha$-subunit in the groove between transmembrane segments 1, 2, 4, 5 and 6 and their extracellular loops. In our published model of a

Table 3 Comparison between the relative $\mathrm{IC}_{50}$ values for a series of ouabain analogues

Relative $\mathrm{IC}_{50}$ values

\begin{tabular}{|c|c|c|c|c|}
\hline & \multicolumn{2}{|c|}{$\left[{ }^{3} \mathrm{H}\right]$ ouabain replacement } & \multicolumn{2}{|c|}{$\mathrm{Na}, \mathrm{K}$-ATPase inhibition } \\
\hline & This study & {$[26]$} & This study & [26] \\
\hline Ouabain & 1 & 1 & 1 & 1 \\
\hline Digoxin & 11.6 & 2.1 & 4.2 & 2.1 \\
\hline Dihydro-ouabain & 1.2 & 22.9 & 1.0 & 2.4 \\
\hline Digoxigenin & 0.25 & 11.1 & 0.66 & 0.8 \\
\hline Strophanthidin & 0.10 & 10.4 & 0.14 & 1.42 \\
\hline Ouabagenin & 0.70 & 311 & 2.0 & 2.2 \\
\hline
\end{tabular}

Ouabain analogues are obtained in the present study and by Paula et al. [26]
QN type Na,K-ATPase [13], the rhamnose unit is directed to the extracellular space, whereas the lactone ring is oriented deeply into the membrane. A similar model is postulated by Munson et al. [27], although, in part, other amino acid residues found by us are close to the ouabain molecule. Especially, the lactone ring is positioned deeper in the binding pocket, which is due to relaxation of the model during the docking experiment. In our opinion, both docking models are plausible. Keenan et al. [28] have postulated a model in which the lactone ring is located close to the extracellular space and the rhamnose is embedded deeply into the membrane. The latter orientation does not fit with earlier nuclear magnetic resonance studies showing that the rhamnose has a high mobility [29].

$\mathrm{Glu}^{312}$ is a residue that, in the models of both Qiu et al. $[13,14]$ and Munson et al. [27], forms a hydrogen bridge with the rhamnose. In gastric H,K-ATPase, this residue is an Arg, whereas in non-gastric H,K-ATPase, it is an Asp. The presence of a Glu on this position was shown to be necessary for high-affinity ouabain binding in both $\mathrm{H}, \mathrm{K}$ ATPases $[13,14]$. The binding affinity of ouabain in mutant E312R of human Na,K-ATPase [30] was much lower than that of wild-type enzyme. However, there was no difference in binding affinity when the binding of the sugarless ouabagenin was measured. This strongly supports the models with the rhamnose residue at the extracellular border of the membrane. In our QN rat model, Glu312 always plays a crucial role in sugar binding, also with digoxin where a large tridigitoxose is present.

Docking experiments with the ouabain analogues in the $\mathrm{Na}, \mathrm{K}-\mathrm{ATPase}(\mathrm{QN})$ model gave rather variable results. Although they all bound to the enzyme within the same pocket, they bound in part to different residues due to presence or absence of a sugar residue and to the different groups present at the steroid skeleton. This led to unexpected changes in binding parameters. One could expect that ouabagenin would have a much lower affinity than ouabain because the sugar that binds with several hydrogen bonds to $\mathrm{Na}, \mathrm{K}$-ATPase is absent in ouabagenin. The biochemical studies show a roughly similar affinity for ouabain and ouabagenin for the QN mutant of $\mathrm{Na}, \mathrm{K}$ ATPase. Radkov et al. [30] even found a twofold lower Ki value for ouabagenin than for ouabain. In the docking experiment, ouabagenin penetrated the membrane more deeply, resulting in hydrogen bridges of the lactone ring with residues of M8. Even more striking is our finding that the apparent affinity for digoxigenin in Na,K-ATPase (QN) is 6-35 times higher than that of digoxin. It might be that the absence of the long hydrophilic trisdigitoxose gives this genin also the chance to penetrate more deeply into the membrane and form hydrogen bridges that could not occur when the sugar is present in the molecule. A deeper penetration into the membrane might also explain the 
relatively high affinity of $\mathrm{Na}, \mathrm{K}$-ATPase (QN) for strophanthidin and ouabagenin.

The wild-type non-gastric H,K-ATPase has a very low affinity for ouabain and the five tested analogues. By mutation of only five residues resulting in the mutant EGPLC, it was possible to obtain a high affinity for ouabain. In the oocyte system, it had a similar affinity for ouabain as the QN-mutant of Na,K-ATPase [14]. In the present study using baculovirus expressed enzymes, it had in the $\left[{ }^{3} \mathrm{H}\right]$ ouabain replacement studies four times lower apparent affinity than the Na,K-ATPase (QN) whereas in the ATPase inhibition studies, the apparent affinities were similar (Table 1). The EGPLC mutant had in both assays a 5-6 times higher affinity for digoxin than for ouabain compared to Na,K-ATPase (QN). The apparent affinity for digoxigenin, strophanthidin and ouabagenin was a factor 3-13 (depending on compound and assay method) lower than for ouabain. Strikingly, the apparent affinity for dihydro-ouabain in the EGPLC mutant was much higher (46 times in the ATPase assay and 86 times in the ouabain replacement studies) than for $\mathrm{Na}, \mathrm{K}-\mathrm{ATPa}$. The only difference between dihydroouabain and ouabain is the absence of a double bond in the lactone ring of the former compound. This absence leads to another orientation of the lactone ring with respect to the steroid skeleton. It is likely that in the binding pocket of $\mathrm{Na}, \mathrm{K}$-ATPase, there is enough space for both orientations, whereas this is not the case in the EGPLC mutant. The catalytic subunits of Na,K-ATPase and the EGPLC mutant of non-gastric H,K-ATPase are only for $60 \%$ similar. The EGPLC mutant of non-gastric H,K-ATPase has only mutations in M4, M5 and M6, which was sufficient for obtaining a high-affinity for ouabain. It might be that one or more residues outside M4-M6 stick into the binding pocket without effect on the binding of ouabain but hampering the binding of dihydro-ouabain by occupying the position of the differently oriented lactone ring.

Open Access This article is distributed under the terms of the Creative Commons Attribution Noncommercial License which permits any noncommercial use, distribution, and reproduction in any medium, provided the original author(s) and source are credited.

\section{References}

1. Axelsen KB, Palmgren MG (1998) Evolution of substrate specificities in the P-type ATPase superfamily. J Mol Evol 46:84-101

2. Codina J, Delmasmata JT, Dubose TD (1998) The a-subunit of the colonic $\mathrm{H}^{+}, \mathrm{K}^{+}$-ATPase assembles with $\mathrm{b} 1-\mathrm{Na}^{+}, \mathrm{K}^{+}$-ATPase in kidney and distal colon. J Biol Chem 273:7894-7899
3. Kraut JA, Hiura J, Shin JM, Smolka A, Sachs G, Scott D (1998) The $\mathrm{Na}^{+}-\mathrm{K}^{+}$-ATPase beta 1 subunit is associated with the HK alpha 2 protein in the rat kidney. Kidney Int 53:958-962

4. Swarts HGP, Koenderink JB, Willems PHGM, De Pont JJHHM (2005) The non-gastric H,K-ATPase is oligomycin-sensitive and can function as an $\mathrm{H}^{+}, \mathrm{NH}_{4}^{+}$-ATPase. J Biol Chem 280:3311533122

5. Koenderink JB, Swarts HGP, Hermsen HPH, De Pont JJHHM (1999) The beta-subunits of $\mathrm{Na}^{+}, \mathrm{K}^{+}$-ATPase and gastric $\mathrm{H}^{+}, \mathrm{K}^{+}$ATPase have a high preference for their own alpha-subunit and affect the $\mathrm{K}^{+}$affinity of these enzymes. J Biol Chem 274:1160411610

6. Pestov NB, Korneenko TV, Shakhparonov MI, Shull GE, Modyanov NN (2006) Loss of acidification of anterior prostate fluids in Atp12a-null mutant mice indicates that nongastric H-KATPase functions as proton pump in vivo. Am J Physiol Cell Physiol 291:C366-C374

7. Swarts HGP, Koenderink JB, Willems PHGM, De Pont JJHHM (2007) The human non-gastric H,K-ATPase has a different cation specificity than the rat enzyme. Biochim Biophys Acta 1768:580 589

8. Cougnon M, Bouyer P, Planelles G, Jaisser F (1998) Does the colonic H,K-ATPase also act as an Na,K-ATPase. Proc Natl Acad Sci USA 95:6516-6520

9. Grishin AV, Caplan MJ (1998) ATP1AL1, a member of the nongastric H,K-ATPase family, functions as a sodium pump. J Biol Chem 273:27772-27778

10. Price EM, Lingrel JB (1988) Structure-function relationships in the Na,K-ATPase a subunit: site-directed mutagenesis of glutamine111 to arginine and asparagine- 122 to aspartic acid generates a ouabain-resistant enzyme. Biochemistry 27:8400-8408

11. Koenderink JB, Hermsen HPH, Swarts HGP, Willems PHGM, De Pont JJHHM (2000) High-affinity ouabain binding by a chimeric gastric $\mathrm{H}^{+}, \mathrm{K}^{+}$-ATPase, containing transmembrane hairpins M3M4 and M5-M6 at the a1-subunit of rat $\mathrm{Na}^{+}, \mathrm{K}^{+}$-ATPase. Proc Natl Acad Sci USA 97:11209-11214

12. Qiu LY, Koenderink JB, Swarts HGP, Willems PHGM, De Pont JJHHM (2003) Phe783, Thr797, and Asp804 in transmembrane hairpin M5-M6 of $\mathrm{Na}^{+}, \mathrm{K}^{+}$-ATPase play a key role in ouabain binding. J Biol Chem 278:47240-47244

13. Qiu LY, Krieger E, Schaftenaar G, Swarts HGP, Willems PHGM, De Pont JJHHM, Koenderink JB (2005) Reconstruction of the complete ouabain-binding pocket of $\mathrm{Na}, \mathrm{K}$-ATPase in gastric $\mathrm{H}, \mathrm{K}$ ATPase by substitution of only seven amino acids. J Biol Chem 280:32349-32355

14. Qiu LY, Swarts HGP, Tonk EC, Willems PHGM, Koenderink JB, De Pont JJHHM (2006) Conversion of the low-affinity ouabainbinding site of non-gastric H,K-ATPase into a high-affinity binding site by substitution of only five amino acids. J Biol Chem 281:13533-13539

15. Price EM, Rice DA, Lingrel JB (1990) Structure-function studies of $\mathrm{Na}, \mathrm{K}$-ATPase. Site-directed mutagenesis of the border residues from the H1-H2 extracellular domain of the alpha subunit. J Biol Chem 265:6638-6641, 1

16. Klaassen CHW, Van Uem TJF, De Moel MP, De Caluwé GLJ, Swarts HGP, De Pont JJHHM (1993) Functional expression of gastric H,K-ATPase using the baculovirus expression system. FEBS Lett 329:277-282

17. Klaassen CHW, Swarts HGP, De Pont JJHHM (1995) Ethanol stimulates expression of functional $\mathrm{H}^{+}, \mathrm{K}^{+}$-ATPase in Sf9 cells. Biochem Biophys Res Commun 210:907-913

18. Peterson GL (1983) Determination of total protein. Meth Enzymol 91:95-106

19. Swarts HGP, Klaassen CHW, Schuurmans Stekhoven FMAH, De Pont JJHHM (1995) Sodium acts as a potassium analog on gastric H,K-ATPase. J Biol Chem 270:7890-7895 
20. Toyoshima C, Nomura H, Tsuda T (2004) Lumenal gating mechanism revealed in calcium pump crystal structures with phosphate analogues. Nature 432:361-368

21. Hooft RW, Vriend G, Sander C, Abola EE (1996) Errors in protein structures. Nature 381:272

22. Kramer B, Rarey M, Lengauer T (1999) Evaluation of the FLEXX incremental construction algorithm for protein-ligand docking. Proteins 37:228-241

23. Allen FH (2002) The Cambridge Structural Database: a quarter of a million crystal structures and rising. Acta Crystallogr B 58:380388

24. Krieger E, Darden T, Nabuurs SB, Finkelstein A, Vriend G (2004) Making optimal use of empirical energy functions: force field parametrization in crystal space. Proteins, in press

25. Krieger E, Nielsen JE, Spronk CA, Vriend G (2006) Fast empirical pKa prediction by Ewald summation. J Mol Graph Model 25:481-486

26. Paula S, Tabet MR, Ball WJ Jr (2005) Interactions between cardiac glycosides and sodium/potassium-ATPase: three-dimensional structure-activity relationship models for ligand binding to the E2-Pi form of the enzyme versus activity inhibition. Biochemistry 44:498-510

27. Munson K, Law RJ, Sachs G (2007) Analysis of the gastric H,K ATPase for ion pathways and inhibitor binding sites. Biochemistry 46:5398-5417

28. Keenan SM, DeLisle RK, Welsh WJ, Paula S, Ball WJ Jr (2005) Elucidation of the $\mathrm{Na}^{+}, \mathrm{K}^{+}$-ATPase digitalis binding site. J Mol Graph Model 23:465-475

29. Middleton DA, Rankin S, Esmann M, Watts A (2000) Structural insights into the binding of cardiac glycosides to the digitalis receptor revealed by solid-state NMR. Proc Natl Acad Sci USA 97:13602-13607

30. Radkov R, Kharoubi-Hess S, Schaer D, Modyanov NN, Geering K, Horisberger JD (2007) Role of homologous ASP334 and GLU319 in human non-gastric $\mathrm{H}, \mathrm{K}$ - and Na,K-ATPases in cardiac glycoside binding. Biochem Biophys Res Commun $356: 142-146$ 